Columbia Law School

Scholarship Archive

2019

\title{
Open Plurilateral Agreements, International Regulatory Cooperation and the WTO
}

\author{
Charles F. Sabel \\ Columbia Law School, csabel@law.columbia.edu \\ Bernard Hoekman \\ European University Institute, Robert Schuman Centre for Advanced Studies (RSCAS)
}

Follow this and additional works at: https://scholarship.law.columbia.edu/faculty_scholarship

Part of the International Trade Law Commons

\section{Recommended Citation}

Charles F. Sabel \& Bernard Hoekman, Open Plurilateral Agreements, International Regulatory Cooperation and the WTO, Global Policy, Vol. 10, P. 297, 2019; Robert Schuman Centre for AdVANCEd Studies, Global Governance Programme EUI Working PaPer No. RSCAS 2019/10 (2019).

Available at: https://scholarship.law.columbia.edu/faculty_scholarship/2304

This Working Paper is brought to you for free and open access by the Faculty Publications at Scholarship Archive. It has been accepted for inclusion in Faculty Scholarship by an authorized administrator of Scholarship Archive. For more information, please contact scholarshiparchive@law.columbia.edu, rwitt@law.columbia.edu. 

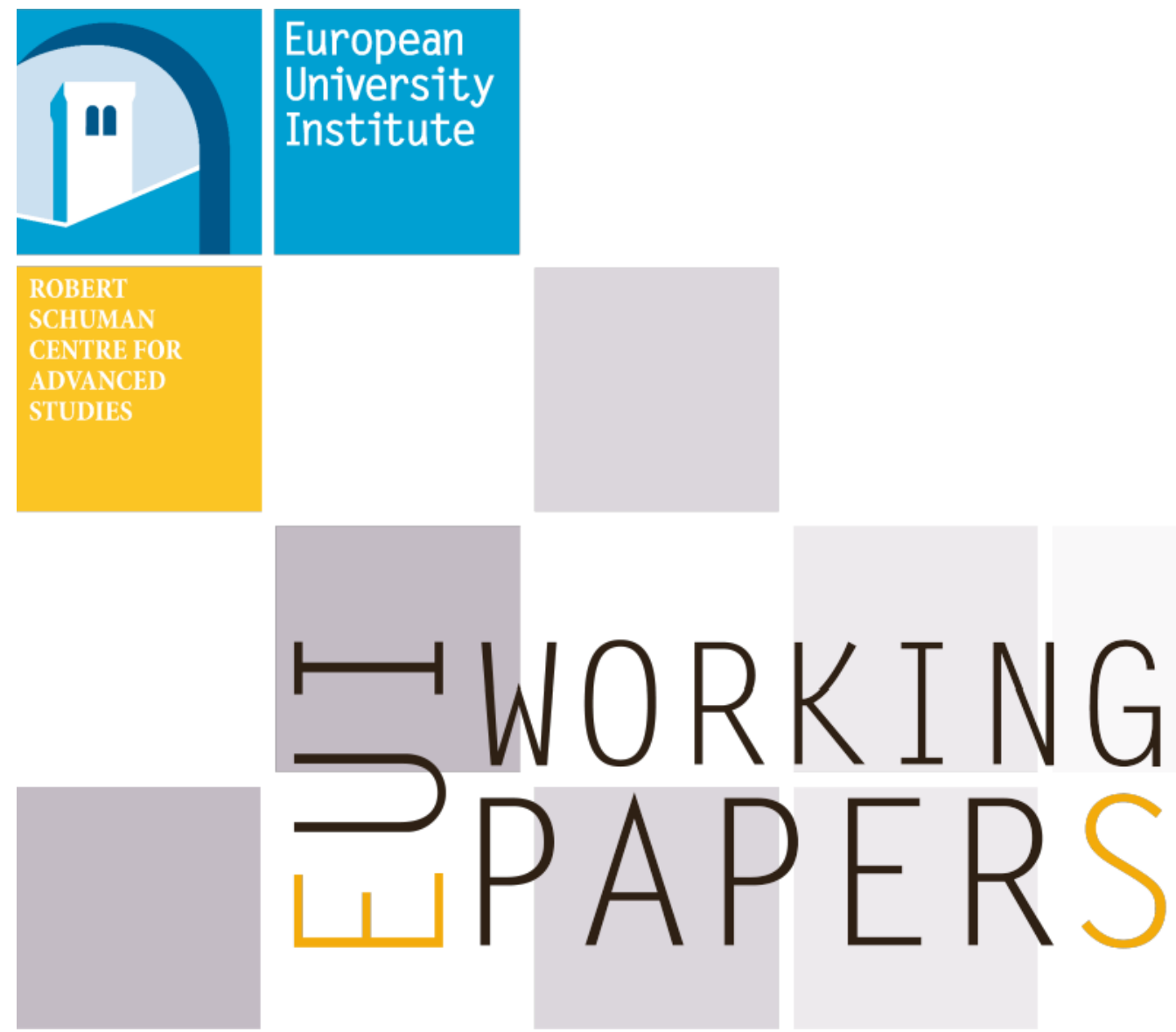

RSCAS 2019/10

Robert Schuman Centre for Advanced Studies Global Governance Programme-335

Open Plurilateral Agreements, International Regulatory Cooperation and the WTO

Bernard Hoekman and Charles Sabel 
European University Institute

Robert Schuman Centre for Advanced Studies

Global Governance Programme

Open Plurilateral Agreements, International Regulatory Cooperation and the WTO

Bernard Hoekman and Charles Sabel

EUI Working Paper RSCAS 2019/10 
This text may be downloaded only for personal research purposes. Additional reproduction for other purposes, whether in hard copies or electronically, requires the consent of the author(s), editor(s). If cited or quoted, reference should be made to the full name of the author(s), editor(s), the title, the working paper, or other series, the year and the publisher.

ISSN 1028-3625

(C) Bernard Hoekman and Charles Sabel, 2019

Printed in Italy, February 2019

European University Institute

Badia Fiesolana

I - 50014 San Domenico di Fiesole (FI)

Italy

www.eui.eu/RSCAS/Publications/

www.eui.eu

cadmus.eui.eu 


\section{Robert Schuman Centre for Advanced Studies}

The Robert Schuman Centre for Advanced Studies, created in 1992 and currently directed by Professor Brigid Laffan, aims to develop inter-disciplinary and comparative research on the major issues facing the process of European integration, European societies and Europe's place in $21^{\text {st }}$ century global politics.

The Centre is home to a large post-doctoral programme and hosts major research programmes, projects and data sets, in addition to a range of working groups and ad hoc initiatives. The research agenda is organised around a set of core themes and is continuously evolving, reflecting the changing agenda of European integration, the expanding membership of the European Union, developments in Europe's neighbourhood and the wider world.

For more information: http://eui.eu/rscas

The EUI and the RSCAS are not responsible for the opinion expressed by the author(s).

\section{The Global Governance Programme}

The Global Governance Programme is one of the flagship programmes of the Robert Schuman Centre. It is a community of outstanding professors and scholars, that produces high quality research and engages with the world of practice through policy dialogue. Established and early-career scholars work on issues of global governance within and beyond academia, focusing on four broad and interdisciplinary areas: Global Economics, Europe in the World, Cultural Pluralism and Global Citizenship.

The Programme also aims to contribute to the fostering of present and future generations of policy and decision makers through its executive training programme: the Academy of Global Governance, where theory and 'real world' experience meet and where leading academics, top-level officials, heads of international organisations and senior executives discuss on topical issues relating to global governance.

For more information: http://globalgovernanceprogramme.eui.eu

The European University Institute and the Robert Schuman Centre are not responsible for the opinions expressed by the author(s). 


\begin{abstract}
Sustained high growth in many developing countries ('the rise of the rest') combined with long-standing WTO working practices hampers the ability of the WTO to perform its routine functions and paralyzes efforts to adapt to new circumstances. Preferential trade agreements have taken up some of the slack in addressing differences in domestic regulation of product safety, environmental and social conditions, but are exclusionary and inefficient from a global perspective. In this paper, we argue that a new type of agreement based on open plurilateral cooperation offers better prospects for groups of countries to explore and develop their potential common interests on regulatory matters, while safeguarding core aspects of their national regulatory sovereignty and in-creasing the possibility of regenerating the WTO from within.
\end{abstract}

\title{
Keywords
}

Regulation, international cooperation, trade, WTO, plurilateral agreements 


\section{Introduction*}

Rapid growth in developing economies ('the rise of the rest') combined with long-standing working practices hampers the ability of the World Trade Organization (WTO) to perform its routine functions and paralyzes efforts to adapt to new circumstances, above all the decreasing importance of tariffs and the increasing importance of regulatory differences as impediments to trade. Differences in domestic regulation of product safety, environmental and social conditions are often being addressed in preferential trade agreements (PTAs), typically among regional trading partners (e.g., the Comprehensive and Progressive Agreement for Transpacific Partnership) or between a trading area and a key partner (e.g., the Comprehensive Economic and Trade Agreement between Canada and the EU). ${ }^{1}$ Such agreements exclude WTO members not party to them and thus are as much or more a device for opting out of the current system as for augmenting it. Because they are broad trade deals-more limited variants of the regime embodied by the WTO-PTAs are as likely to be challenged politically as instruments of an excessive and unwanted globalization as the WTO itself. Despite, indeed often because of their innovative ambitions, PTAs do little to extend the reach of multilateral rulemaking to urgent new topics while rendering the institutional foundations of global trade more fragile.

In parallel to the expansion in use of PTAs, extensive regulatory coordination occurs outside the WTO. ${ }^{2}$ In the case of trade in some environmentally sensitive goods, such as forest products and palm oil, concerns that commerce in these goods does not further threaten endangered species, contribute to deforestation or undermine the rights of native communities have led to the emergence of a substantial thatching of national laws barring, for example, import of wood harvested in violation of various legal requirements and a profusion of NGO-sponsored international standards for sustainable forestry. Because they are not discriminatory, the resulting regimes do not, like PTAs, undermine the WTO. The burden of coordinating consistent implementation and enforcement of many similar yet subtly different norms and procedures are great; and the strains of bearing that burden, together with many other signs of fragility, reinforce, if only indirectly, the sense we can no more count on the spontaneous selforganization of states and NGOs facing common threats to protect core values in global commerce than we can rely on the comprehensive, top-down response of PTAs.

This essay extrapolates from successful cases of far-ranging or deep international regulatory cooperation in domains such as food safety, civil aviation and pharmaceuticals to propose a novel vehicle-formally organized as multilateral agreements to avoid the pitfalls of PTAs and patchwork regimes - for groups of countries to develop potential common interests in regulatory matters within the WTO, while safeguarding key aspects of their national regulatory sovereignty. We call this vehicle the open plurilateral agreement (OPA) and argue that it is valuable in and of itself; that the WTO has multiple roles - ranging from the provision of capacity-building services to dispute resolution - to play in establishing such an institutional facility; and that doing so can support the regeneration of the WTO from within. ${ }^{3}$ The proposal is at once a concrete project for reform and a heuristic for understanding the

\footnotetext{
We are grateful to Robert Basedow, Thomas Bollyky, Marco Bronckers, Paola Conconi, Philipp Genschel, Sean Heather, David Levi-Faur, Nuno Limão, Patrick Low, Aaditya Mattoo, Petros Mavroidis, Peter Mumford, Julie Nind, Dani Rodrik, Richard Stewart, Robert Wolfe, Jonathan Zeitlin, two referees and participants in the WTO Trade Dialogue: Updating Trade Cooperation: An Economic View, Geneva, December 11, 2018 and for helpful comments. The project leading to this paper has received funding from the European Union's Horizon 2020 research and innovation program under grant agreement No 770680.

1 See e.g., Dür, Baccini and Elsig (2014) and Hofmann, Osnago and Ruta (2018). Palanco and Sauvé (2018) describe and discuss the coverage of regulatory cooperation chapters in recent trade agreements.

2 Overdevest and Zeitlin (2018a, b) and Pacheco et al. (2018).

3 Open plurilateralism as an organizing concept is an element of the Government of New Zealand's trade policy strategy. See Vitalis (2018).
} 
mismatch between current developments in trade and the governance of the WTO and how conceptually to come to grips with it.

OPAs are agreements authorizing regulatory authorities in various domains to cooperate to reduce the costs of exporting goods and services produced in their jurisdiction to other member countries ${ }^{4}$ subject to critical, continuing determination by the regulators themselves and their national political oversight bodies, that products and production processes meet evolving national standards. Cost reductions can be achieved when regulatory authorities accept, upon mutual examination, a determination by their counterparts that an exporter's products conform to the importer's standards, eliminating redundant compliance checking. Ultimately, going much further, authorities in OPA member countries may upon additional mutual scrutiny recognize that, differences in their respective standards or conformance tests notwithstanding, their systems produce equivalent decisions, making approval by one tantamount to approval by the other, subject again to continuing verification that this is the case.

OPAs differ from PTAs in three ways. First, PTAs are comprehensive trade deals and thus entail cross-issue linkages. ${ }^{5}$ A commitment in domain A may, as part of an encompassing bargain, be compensated by concessions in domain B. OPAs are domain-specific: commitments or cooperation in one domain are not bargaining chips in negotiations about policies in others. Second, PTAs are enduring, detailed agreements, fixing the terms of trade for the foreseeable future, subject only to presumably marginal periodic adjustments. OPAs establish frameworks for continuing reciprocal review of existing regulatory standards and their implementation, and joint evaluation of potential alternatives and adaptions to new developments. Put another way, OPAs entrench particular values more deeply than PTAs, but treat the precise expression of those values in regulatory rules as more easily contestable and corrigible. Because they treat standards as values in themselves, expressive of deep and abiding social and political commitments, rather than counters in periodic rounds of trade bargaining, and because they institutionalize ongoing review of the interpretations and elaboration of those commitments, OPAs make it easier for nations to assert distinctive aspects of their sovereignty than PTAs. They also make it easier for polities, wary of elites that have proven inattentive to repercussions of globalization, to hold regulatory authorities and their political overseers to account.

The third difference between PTAs and OPAs concerns the conditions under which countries not party to the original agreements can subsequently join. To conform to the rules of the WTO, so that parties to a PTA can be simultaneously members of the WTO, PTAs must be comprehensive, covering "substantially all trade" between the parties. To accede to a PTA a new member must agree to all the terms of the elaborate compromise struck by the original signatories. In practice this makes PTAs closed agreements. (Just how closed PTAs can be is demonstrated by Great Britain's difficulties withdrawing from the EU: all the commercially feasible alternatives to membership entail continuing, deep engagement with EU regulators - at odds with the reassertion of national sovereignty that motivated Brexit-and reestablishing deep regulatory cooperation after even a brief interruption would be prohibitively costly.)

Because they are domain-specific, accession to an OPA requires a narrower and more limited commitment than a PTA. A candidate member must only undertake to meet the regulatory requirements established by OPA members as these apply to the particular class of goods or services covered by the agreement. Insofar as members of an OPA require only equivalent performance-not identical procedures or institutions - in conformance testing, standard setting and enforcement in each domain, they permit candidate members to produce the required regulatory outcome by the process best suited to their own traditions and conditions. In contrast to a PTA, accession to an OPA can be achieved

\footnotetext{
4 See e.g., OECD (2017) for a review of the significance of such costs.

5 Issue linkage is a key feature of trade agreements and efforts to extend their coverage to nontrade issues such as domestic regulation. See e.g., Conconi and Perroni (2002); Limão (2005; 2016), Maggi (2016).
} 
stepwise, with candidate members establishing the equivalence of their methods in one phase of the regulatory process, or one or another product of a particular class, then another, and another, so that trade expands and collaboration deepens even when full equivalence of regulatory systems is a distant goal. For all these reasons we call this type of plurilateral agreement open.

Acknowledging OPAs as WTO-conforming could assist countries to reduce the international trade costs of regulatory heterogeneity and help regenerate the WTO as a forum for mutually beneficial cooperation on trade-related policies. Put starkly, the WTO has failed as a forum for preparing the (re-)negotiation of comprehensive trade deals. Its operation reflects the consensus of its members, while doing too little to shape it, or more modestly, even to aid members in the reconsideration of their positions. This could change if the WTO not only recognizes the legitimacy of OPAs - something that is currently the subject of lively debate among WTO members - but becomes a clearing house for comparing and diffusing their results and gradual expansion of membership. In principle, the WTO can provide a platform to support gradual multilateralization of OPAs through provision of technical support to candidate members and resolving disputes between OPAs and counties seeking to accede to them. Through the formation of OPAs with different geographic scope and substantive reach, groups of WTO member countries could both test and re-elaborate alternative regulatory standards and designs for institutional cooperation. The growth or decline of OPAs would demonstrate the attractiveness to newcomers of those that survive this winnowing. In this way OPAs, operating under auspices of the WTO would be dynamic and flexible vehicles by which member states come to reconsider their particular regulatory commitments and institutional habits in light of the experience of like-minded others. The most successful approaches could serve as the starting points for generalization and codification in international standards or international framework agreements of various kinds.

A WTO hospitable to OPAs would no longer be hostage to the consensus of its members but be a partner in articulating it. A WTO that admitted of OPAs would create fora in which members could address commercially urgent, politically sensitive problems of regulatory coordination without embedding them in comprehensive deals spanning many policy areas, concluded in secrecy, and typically shielded from democratic accountability. Continuing reviews of agreements struck in such fora would bring to light and reconcile varying interpretation of norms before they result in conflicting enforcement strategies. By embracing OPAs the WTO would reduce the dangers of fragmentation from within and the risks of creating, at the margins of the global trade order, ad hoc, patchwork - and therefore typically fragile - regimes to deal with important collective action problems.

The remainder of this essay is organized as follows. Part 2 discusses briefly how the successes of earlier rounds of trade liberalization and changes in the organization of production have made regulation - and importantly regulation requiring deep and continuing cooperation to establish the equivalence of trade partners' regimes - an increasingly prominent issue in trade relations. We then present case studies of two kinds of regimes that most closely approximate OPAs, starting with the bottom-up development of the expansive regime to regulate trade in forest products. This type of regime is pluralistic, but incompletely integrated. Only recently has there been a proliferation of the institutions for mutual monitoring and review that would make for effective implementation and enforcement of its norms. Its development illustrates the possibilities but also the difficulties of achieving cooperation without any overarching institutional support of the kind inclusion in a reformed WTO could provide. Moreover, to better understand the operation of governance based on regulatory equivalence, we consider an alternate approximation to OPAs: bilateral regimes that are deeply integrated through joint review and deliberation. The case studies here are of food safety and civil aviation, typical of the kinds of arrangements, based on treaties or executive agreements, that have emerged ad hoc in response to the manifest need for close, regular collaboration in the absence of generally accepted methods for institutionalizing it.

In Part 3 we take up the blockages in the WTO. For analytic purposes we distinguish immediate or proximate drivers of obstruction having to do with changes in the external environment and the WTO's working practices from structural or root causes having to do with the very constitution of the WTO 
itself as the embodiment of a particular understanding of how to regulate global trade. Among the proximate causes figure the redistribution of power from the advanced to developing countries, the backlash against trade as one emblem of a threatening globalization in many of the advanced countries, and the understanding of consensus rules that has come to be habitual in WTO decision making. Of the fundamental causes, most significant is surely the assumption that trade is self-evidently a global problem, and as such should be regulated by a single, comprehensive multilateral agreement, adopted and periodically renewed by consensus of the members acting as a sovereign body. From this it followed that the only international trade agreements compatible with the WTO itself are either those that effectively exclude other members but reflect comprehensive ambitions and "sovereign" legitimation on a smaller scale-PTAs, covering "substantially all trade" of signatories as homuncular versions of the WTO - or narrower, domain-specific agreements that can be nested in the WTO because they are subject explicitly or implicitly to consensus requirements of the body of members as a whole.

Two options exist for such domain-specific agreements among a subset of the WTO membership: Plurilateral Agreements (PAs) allowing signatories to discriminate against nonparties if all WTO members assent to their registration, and critical mass agreements that, in contrast, do not require consensus because they do not discriminate against non-parties. The latter create free rider problems, because newcomers have the trade benefits accorded to the original parties without undertaking the regulatory adjustments required of the initiators. In Part 4 we turn to OPAs as an alternative form of smaller group cooperation. Precisely because OPAs authorize and encourage a process of consensus building and transformation that is (initially) partial, involving some but not all of the members, and are embedded in the routine operation of the WTO, rather than accorded the legitimating dignity of deliberation in a "constituent" or "sovereign" bargaining round, they seem to offend the very constitution of the WTO. We argue to the contrary. Because OPAs are provisional, placing regulatory cooperation under continuing democratic control, they are respectful of national sovereignty and thus deeply consistent with the legitimating principles of the WTO. Yet they also offer a mechanism for the generation of rich and reliable norms to guide commerce and, when necessary, direct adjudication. In regulatory affairs, as in advanced contracting among jointly innovating firms, the very process of determining whether each party's efforts is serving the joint purpose clarifies that purpose, helps the parties better achieve it, and allows each to assess whether the other has the intention and capacity to do so. Put another way, and connecting our proposal for OPAs to a current of thought in international relations that reaches back to the work of Chayes and Chayes $(1993 ; 1998)$ on the new sovereignty, the very articulation of norms touches off a process of social learning that helps the actors adhere to them, or understand early on - before much harm is done - that a counterpart will or cannot.

\section{International regulatory cooperation: the future is on the way}

Regulation has become more prominent in trade in part simply because earlier rounds of trade negotiations dramatically reduced tariffs. In trade between advanced countries tariffs in most goods are now at nuisance levels in that collection costs may exceed the revenue they produce. Regulations become more conspicuous as perceived barriers to trade because other restrictions have been removed. The deeper causes of the increased importance, and changing nature of regulation in trade are to be sought in three long-term changes in the organization of production generally, in agriculture or mining as well as many services and manufacturing industry. All are responses to the uncertainties created by unpredictable swerves in the direction of technological change and dramatic volatility in markets; they often are grouped together under the omnibus term globalization.

\subsection{Why regulation has become more prominent in trade}

The first is vertical dis-integration: The decomposition of production into discreet tasks (the manufacture of particular components, research and development, final assembly) accomplished by independent firms collaborating with many clients and linked to each other and the final producer in supply chains 
(Baldwin, 2016). The more volatile and uncertain markets became, the riskier it was for vertically integrated producers to own component suppliers whose products could abruptly become obsolete because of unforeseen innovation or superfluous because of a shift in demand. The second is the globalization of supply chains. Production facilities are located where the costs of production are lowest, or where they can serve important markets with distinct characteristics. The third is the shift within these supply chains to just-in-time or continuous improvement production and design systems based on immediate error detection and correspondingly short learning cycles. Traditional producers hedged against breakdowns by holding large buffer inventories of work-in-progress. Uncertainty increased the cost of these hedges, just as it increased the costs of owning suppliers. Firms responded by eliminating the buffers-ideally producing one piece at a time. Breakdowns thus stop production, and operations only resume when the disruption is traced to its source and corrected.

These dynamics have transformed trade, increasing the centrality of regulation and changing the scope and character of the regulator's responsibility. Vertical disintegration and the rise of global supply chains produces enormous increases in intra-firm and intra-industry trade as exports are typically composed of many imported components and subassemblies. Just-in-time production makes delays and disruptions ruinously costly. Regulators must not only accommodate greatly increased trade volumes; their own operations must be as friction-free as the flows of goods and services they regulate.

The changes in the organization of production put new burdens on regulators domestically and increase the need for collaboration with capable foreign peers. Globalization responds to and further accelerates the increased pace of innovation. Final producers, no longer limited by the technological choices of their internal production units, as in the days of vertical integration, collaborate with capable suppliers to rapidly combine novel technologies in new products. But more rapid innovation increases the risk of introducing latent hazards: hidden defects that go unnoticed when products initially are approved for sale. The regulator's traditional emphasis on fixing, ex ante, conditions for market operators, and assuring compliance with them proves too limited. Ex ante or pre-marketing review and approval is being complemented by greatly increased attention to post-post-approval or ex post monitoring of the performance of the good or service in the market. This change is marked by the diffusion of requirements, mandated by public regulation and by private standards enforced by contract among supply chain partners, to report breakdowns in control that threaten the safety of products or production processes, to trace these incidents to their source and root cause, and to take corrective and preventative action. The just-in-time disciplines that enable smooth operation within supply chains also equip firms to detect and report such breakdowns.

The need for an increased, and increasingly fine-meshed international regulatory cooperation follows directly. In a world where inputs are globally sourced and potentially hazardous products globally distributed, regulatory systems must encompass relevant trade partners to be effective. National regulatory systems that provide early warning of possible dangers in the goods traded among them, and respond quickly to breakdowns, must have confidence in one another's oversight of the linked producers. Amidst rapid change that confidence can only be maintained by ongoing scrutiny of partners' regulatory practices in particular domains and joint investigation and, perhaps mutual adjustment, when differences and failures are detected - all without jeopardizing the right of unilateral withdrawal from agreements that is the continuing prerogative of sovereignty.

At its best, such international collaboration allows regulators routinely to reevaluate their own performance in the light of others' successes and failures, improving on the ability of any national regime in isolation effectively to defend the values entrusted to it. When this is so, reductions in trade costs or increased market access and improvements in regulatory control of markets - reflecting shared values and respect for persisting differences - can be complementary, not conflicting. Moreover, and more surprising, given that trade negotiations are often decried today as a technocratic conspiracy against national traditions and the popular will, the continuing and searching mutual examination by regulatory equivalence creates novel possibilities for transparent and publicly accountable decision 
making, and thus for reconciling sovereign self-determination with the stepwise extension of economic exchange and regulatory cooperation.

The pressure for deep international regulatory cooperation of this kind is most urgently felt where the risks of latent hazards, introduced inadvertently by technological change or by the guile of bad actors seeking to profit from deception, are the greatest. Something of this cooperation goes on under the aegis of PTAs. But these pressures can result in stand-alone institutional arrangements under two, contrary sets of conditions. If exporting countries and importing countries have sharply different interests that also diverge within each group, the result is a piecemeal regime or regime complex of the kind observed in forestry and palm products. If, on the contrary, exporters and importers have largely overlapping interests - much trade is intra industry, each country producing components or variants of what the other producers - the result can be a bilateral agreement to seek regulatory equivalence. We take up these cases in turn.

\subsection{The problems and possibilities of building an ad hoc regime}

Deforestation accelerates climate change, destroys irreplaceable habitats, and dislocates communities of first peoples and other forest dwellers. It was almost self-evident that protection of forests by limiting illegal logging and trade in illegally logged timber would figure prominently in the reform agenda that emerged as concern for the environment first crested politically in the early 1990s. Regime building in this domain has proceeded by fits and starts and in bits and pieces. The closer the institutional set up gets to being fully operational, the clearer it becomes that its effectiveness will depend on the kind of deep and continuing regulatory cooperation increasingly central to (but buried within) PTAs and more clearly exposed in the bilateral arrangements to be described next. Whether the current arrangements can formalize the required mutual monitoring and review is an open question. ${ }^{6}$ At the least developments in regulation of trade in illegal logging suggest that it may be possible, under favorable conditions, to create a plurilateral regime with many of the characteristics of an OPA outside (though in conformity with) the WTO, but that the coordination costs of such ad hoc solutions are likely to be dauntingly high. The potential gains from creating an institutional scaffolding to reduce those costs through economies of scale and scope in institution building are correspondingly great.

Early efforts to secure a legally binding, comprehensive convention on forest preservation failed at the 1992 Earth Summit in Rio. In the aftermath the World Wide Fund for Nature (WWF), a British NGO, recognizing the immediate limits of public action, convened stakeholders representing the private sector, environmental organizations, and vulnerable communities - grouped in separate "chambers" and balanced between the Northern and Southern hemispheres - to establish, in the Forest Stewardship Council (FSC), an organization for setting voluntary standards for forest preservation and a system for demonstrating compliance with them. Broad, continuing international discussion under the auspices of the World Bank, the UN Intergovernmental Forum on Forests and the G8 of the need for extensive reform of forestry governance in timber exporting countries in addition to voluntary standards and certification emboldened the EU to unilaterally advance the Forest Law Enforcement, Governance and Trade (FLEGT) action plan in 2003. Under pressure from NGOs, some exporters and new legislation in the US (the Lacey Act), that measure was reinforced by an EU Timber Regulation (EUTR) a decade later. FLEGT created preferential or expedited access to the EU single market for countries-all developing - that cooperate with the EU in fostering sustainable forestry and deterring illegal logging. The EUTR creates important incentives for the extension of these cooperative efforts, and for compliance with the obligations arising under them by imposing potentially substantial penalties on firms that introduce timber into the EU from non-cooperating exporters, or that fail to exercise due diligence in ascertaining that the products they commercialize in fact meet the agreed requirements.

6 This section follows the accounts in Overdevest and Zeitlin (2015, 2018a, 2018b). 
Under FLEGT, wood-exporting countries are invited to enter bilateral Voluntary Partnership Agreements (VPAs) with the EU. A party to a VPA agrees to review and periodically revise its current forestry law and administration with national stakeholders to achieve the aims of FLEGT and international agreements to which it is a signatory; it must also establish a corresponding timber legality assurance system (TLAS) - under the oversight of an independent auditor, but increasingly with civil society participation - to ensure the revised legal requirements are respected from harvesting to export. For its part the EU, to induce agreement to the terms of VPA, facilitates access for FLEGT licensed timber to its market and supports (with the help of donor institutions with the requisite expertise) the capacity building of public and private actors needed for compliance. A joint committee of representatives of the EU and the partner country monitor implementation of the agreement and settle disputes not so intractable as to require arbitration. The joint committee may also recommend adjustments to the agreement, for example in relation to provision of capacity-building services. That the agreements are formally voluntary, jointly governed and provide technical and adjustment assistance. This assuaged concerns about the WTO conformity of the VPAs and helped win the assent of developing countries, whose opposition had earlier frustrated negotiation of a global forest convention.

The Lacey Act amendment and the EUTR produced a cascade of responses that, as intended, increased the scope and grip of the new protections. As of 2018, seven countries including Cameroon, the Central African Republic, and Liberia in Africa; Guyana and Honduras in Latin America and Indonesia and Vietnam in South-east Asia had agreed VPAs. Formal negotiations or preparations for negotiations are underway with eight more, similarly distributed geographically. If all these negotiations succeed, VPA countries will account for close to 80 percent of global trade and EU imports of tropical wood products. Other advanced countries, including Australia and South Korea have enacted outright prohibitions or legislation with deterrent effect on the import of illegally harvested wood. ${ }^{7}$ The leading transnational private forest certification organizations, such as the FSC, have adjusted their standards to meet EUTR requirements.

Increasing participation in the emergent regime has not been matched by advances in effective administration and enforcement. On the contrary, both VPA partner countries and counterpart authorities in the EU and its member states have struggled to comply with their obligations under the agreements, though the pace of progress seems to have increased recently. It took Indonesia, the first country to export FLEGT-licensed timber, nine years from the start of negotiations with the EU to establish a reliable process for doing so; in Ghana, which is expected to follow suit shortly, implementation has taken longer still — and these are the leaders in their cohort. Within the EU, member states were slow to establish competent authorities (CAs), which are responsible under the EUTR for investigating "substantiated concerns" regarding trade in illegal timber reported by third parties, typically civil society organizations; even where CAs existed, they were often slow to develop procedures for verifying operators' compliance with their due-diligence responsibilities. It took four years and a combination of infringement proceedings against stragglers, additional guidance and revisions in the regulation itself to bring essentially all member state into compliance. Only recently has there been an increase in enforcement activities ranging from assessments of due-diligence systems and requests for corrective action to the imposition of fines.

These delays and difficulties should not be surprising. As development banks and donor organizations know too well it is fiendishly difficult to build state capacity in ministries in national capitals; it is still harder to build capacity in the remote provinces - far from central authority, often governed by local satraps whose livelihood is trafficking of various kinds - where illegal logging, and its concealment by the generation of false documents, is often a mainstay of the economy. Problem solving in such settings, as is typically the case with regulation of latent harms, proceeds in steps, with

7 Japan has imposed a system of green public procurement with government registration of compliance with a voluntary code of conduct (communication with Jonathan Zeitlin). 
successive, apparent solutions repeatedly revealing new facets of the initial difficulty until root causes can be exposed and addressed. Not uncovering unexpected difficulties in the prolonged, initial phases of such investigation is more likely a sign of self-deception than precocious success. The source of the EU's difficulties in complying with its own requirements is no mystery either. When the EUTR came into effect the member states had no national systems for making the determinations of the legality of newly marketed wood products expected of exporters under the regulation. Such systems had to be constructed from scratch with the EU even as the definitions of legality and procedures for ascertaining conformity were taking shape in the VPA discussions. Here too reports of rapid, frictionless compliance, had there been any, should have triggered suspicion, not self-satisfaction.

Recent assessments of the FLEGT Action Plan by the European Court of Auditors in 2015 and an independent evaluation team a year later make clear that further progress in implementation and enforcement will depend on intensified cooperation of the actors within the EU and between them and the actors in the VPAs taken separately and together. The new initiatives include joint assessments of progress with the partner countries to establish multi-year roadmaps for implementation and monitoring; creation of tools for early detection of problems; and, in partnership with expert, outside organizations, programs to extract and make available for general use practical lessons of experience under the VPAs in areas such as shipment testing and timber traceability.

These initiatives mesh with and reinforce an explosion of institutionalized cooperation induced by the growing awareness of failures in implementation and enforcement. The European Commission, for example, convenes the CAs five times a year in an EUTR/FLEGT Expert Group to review EUTR enforcement, make authoritative determinations in disputes between producer countries and CAs, and pool information with the aim of defining best practices and issuing guidance. The CAs have on their own established an informal enforcement network, with a confidential website for sharing inspection reports, and notifications of substantiated concerns of illegality. Sub-groups of CAs have begun to map supply chains in high-risk countries and assess the adequacy of companies' due-diligence procedures. This cooperation extends to joint training and inspections; it is increasingly formalized in regular, regional exchanges among CAs from, for example, the Nordic and Baltic countries and the Mediterranean. Finally, both the Commission and the CAs cooperate more and more closely with regulators in the Timber Regulation Enforcement Exchange (TREE), a network connecting public officials, civil society organizations, and business representatives in the EU, US, Australia, Canada, and East Asia along with officials from Interpol to review enforcement developments in high-risk regions. TREE discussions for example led the US Department of Justice to introduce EUTR due diligence requirements into the consent decree entered with a firm alleged to have imported illegal timber, although these requirements are not anticipated in the amended Lacey Act.

The end of the coordination problems is not in sight. To note one of many pressing issues: the EUTR encourages operators to rely on qualified, private legality standard setters and verification organizations such as the FSC, while assigning continuing responsibility for ascertaining the reliability of private system. It is unclear how far that responsibility extends; at the limit, ad absurdum, the operator would have to make its own legality checks to confirm the validity of the audit system's certifications, rendering the latter pointless. Enforcement of the EUTR is the responsibility of member state CAs and courts. Even if CAs follow common guidance with respect to this and other questions of interpretation, courts disagree in their interpretation of regulations, exposing operators to what seems to them, understandably, arbitrary differences in liability. ${ }^{8}$ Some method of harmonizing judgements as well as guidance will have to be found, or even well intentioned actors will despair of participating. Given the continuing and in many respects unforeseeable changes in supply chains and environmental understanding and other imponderables, problems of this type will be unending, or, rather, continue in ever new forms. "Stabilizing" the regime will require further development of the institutions of continuous coordination now proliferating of the kind that would be provided by an OPA, as we will

8 See Asser Institute (2017), IKEA (2018) and Nathan (2018) 
describe below. If they were to succeed, these cooperative measures would likely transform the forest protection thatching into a novel, plurilateral variant, outside the WTO, of the bilateral mutualequivalence regimes discussed next.

\subsection{Regulatory equivalence in trade: bilateral regimes}

The steps leading to the Food Safety Systems Recognition Arrangement - a declaration of regulatory equivalency - recently signed by the Food and Drug Administration (FDA), the Canadian Food Inspection Agency, and the Department of Health of Canada provides another illustration of the general tendencies prompting closer regulatory coordination. Above all, a look at the process of establishing equivalence draws attention to exacting reciprocal scrutiny of regulatory ends and means - and thus presumptively to heightened possibilities for domestic review and accountability in the partner countries - needed to establish confidence that equivalence can work.

In the US, outbreaks of food-borne illness transmitted by leafy greens (especially dangerous because often eaten raw) led California wholesalers to create in 2006 a regime - contractual, but enforced by a state inspectorate-requiring growers to conduct a hazard analysis of the critical control points (HACCP) review of their farms, identifying the points at which pathogens could enter the production process, and proposing and testing methods of avoiding or mitigating those risks. The Food Safety Modernization Act (FSMA) of 2010 codified this regime, extended it to many more products under the jurisdiction of the FDA and established procedures for responding to breakdowns in controls. As the US was modernizing its food safety legislation, Canada was doing the same: like the FSMA, the Safe Food for Canadians Act (SFCA), passed in 2012, mandated HACCP controls for the entire supply chain, incident reporting and traceability; and like the FSMA the SFCA anticipated close cooperation with the regulators in key trading partners. For both countries, the determination proceeded in two steps: first, a careful desk review of the partner's standards and procedures to ascertain how general organizational goals are translated into specific standards and routines, and to verify that the routines are routinely followed. Then observation by field teams of the partner's audit of a range of food-processing plants and reference laboratories to understand how experience on the ground is translated into decisions and documents.

The FDA's desk review began with the development of an International Comparability Assessment Tool (ICAT) for assessing the robustness of a trading partner's food safety system in ten domains such as inspections and responses to outbreaks of food-related illness. ${ }^{9}$ A capable partner authority is expected to conduct "periodic self-assessments and quality assurance reviews" of its inspection and other programs to "determine areas or functions...that need improvement, to develop improvement plans and to establish timelines for implementing improvements;" similarly a robust food-safety system is expected to include periodic review of enforcement actions "to assess areas in need of improvement or corrective action," and update "policies and practices based on findings." The ICAT review also included presentation by Canadian officials at the national and provincial levels of case studies that, starting with source documents such as audit reports, documented the chain of decision making in particular product recalls and enforcement actions against firms, allowing the US reviewers to determine whether the information generated by the Canadian food-safety system was effectively used to serve its expressed goals. This extended desk review was then complemented by weeks of site visits in which a pair of three-member, interdisciplinary US teams (one in the West of Canada, one in the East) prepared to shadow Canadian inspectors in various plants by reviewing their training records, then observed the actual inspection of processing facilities, with attention to the records consulted and interactions with key managers. The entire process is meticulously described in a report in which the FDA reviewers

9 The following draws is based on the FDA's presentation of ICAT, at http://www.fda.gov/downloads/Food/InternationalInteragencyCoordination/UCM331177.pdf. 
recommend "a positive finding of system recognition"-current FDA lingo for a determination of regulatory equivalence. ${ }^{10}$

As a second example illustrating the trajectory and governance mechanisms of sectoral regulatory collaboration based on continuing mutual scrutiny, consider the agreement on "cooperation in the regulation of civil aviation safety" or Bilateral Aviation Safety Agreement (BASA) entered into by the US and EU in 2011. ${ }^{11}$ Civil aviation is, like pharmaceuticals, among the most rigorously and successfully regulated industries: passenger fatalities per 100 million passenger-kilometers flown globally in commercial air transport fell from 0.8 in 1960 to 0.08 in 1980 and 0.03 in 1990; since then it has ranged between 0.05 and $0.01 .{ }^{12}$ The International Civil Aviation Organization (ICAO), formed under the Chicago Convention on International Civil Aviation in 1944, provides the framework for international regulation in the sector. ICAO establishes a "mutual acceptance" regime in which the certification by one signatory that equipment or flight crews under its jurisdiction meet ICAO standards is accepted by other signatories. Mutual acceptance does not amount to agreement of regulatory equivalence for three reasons. First, ICAO only establishes minimum standards; more demanding jurisdictions such as the US, EU, Japan, China, Brazil and Canada insist on more rigorous ones. Second, innovation outpaces the capacity of ICAO's 191 member states to establish new standards, so, for example, it may be impossible to certify designs for next generation equipment under ICAO. Third, even when standards are available and acceptable to all parties, the capacity and willingness to engage in conformance testing varies greatly among the signatories, and some will not accept the certifications of the others. ${ }^{13}$

For all these reasons the states insistent on higher civil aviation standards enter bilateral agreements with peers. Beginning in 1996, the US negotiated BASA's formal framework agreements in which the partner countries by treaty or executive order authorize their respective air safety authorities (called Technical Agents or TAs) to examine and review each other's practices and treat those found equivalent as common technical implementation procedures (TIPs) for certification purposes. Of these agreements the EU-US BASA, covering principally the airworthiness of equipment from design to manufacture and maintenance, as well as conformity to environmental standards, is the most comprehensive and developed, with a formal governance structure for resolution of disputes and possible extension of the agreement to additional areas of air safety. ${ }^{14}$

Like the ICAO, the EU-US BASA establishes the principle of mutual acceptance, but in a distinctive sense: each party insists on compliance with its own, distinct standards, but agrees to rely "to the maximum extent practicable" on the other party's certifications that its products or services do so. ${ }^{15}$ Formally this means that an Airbus designed in the EU must be certified by the TA in the EU, the European Air Safety Agency (EASA) as meeting the airworthiness or "type" requirements of the TA in the US, the Federal Aviation Administration (FAA), and that a maintenance station in the US repairing Airbus equipment must be certified by the FAA as meeting EASA standards.

In practice and by design, this kind of reciprocal acceptance of compliance certifications shades into collaboration and de facto recognition of the equivalence of many standards. With regard to maintenance

10 FDA, Report of the Systems Recognition Assessment of Canada, ND, at

http://www.fda.gov/downloads/Food/InternationalInteragencyCoordination/UCM503960.pdf.

11 EU-US BASA, International Agreements Council Decision of 7 March 2011 concerning the conclusion of the Agreement between the United States of America and the European Community on cooperation in the regulation of civil aviation safety, at http://eur-lex.europa.eu/resource.html?uri=cellar:64d9e1a2-633c-4e91-bbf5053e5ab1b432.0010.02/DOC_1\&format=PDF.

12 See ICAO (2017).

13 See Jennison (2013, pp. 333-50); Eisner and Parker (2016).

14 See Jennison (2013, pp. 338-9).

15 See EU-US BASA (2011, Annex 1, 3.2.4). 
stations, each authority determined before entering the agreement that the other's basic system for quality control and reporting was equivalent to its own, and listed separately in the maintenance annex to the BASA a small number of "special conditions": "requirements [in the relevant regulation of either party] that have been found, based on a comparison of the regulatory maintenance systems, not to be common to both systems and are significant enough that they must be addressed." ${ }^{6}$ Thus EASA can certify a repair facility in the EU performing work on US equipment as meeting FAA requirements only if it complies with EASA's standards and meets the special conditions defined by the FAA. ${ }^{17}$

Similarly, in certifying the design of new aircraft types, the authorities first determined the equivalence of their respective methods of ascertaining an organization's qualification to produce reliable aircraft designs and a manufacture's capacity to maintain a reliable quality control system, and then provided for the exceptional cases where equivalence cannot be presumed. For example, early in the design process, when encountering novel, unregulated design elements (also called "special conditions") ${ }^{18}$ the FAA and EASA, separately or together, can issue new standards maintaining "a level of safety equivalent to that established in the [existing] regulations"; likewise, either authority can waive the obligation to conform with a particular certification requirement when differences are thought to be inconsequential, or find that different design features or test methods achieve an "equivalent level of safety." Only if a difference in the scope and stringency of requirements does not fall under one of these exceptions will one of the authorities find a "Significant Standards Difference" and (if further discussion does not resolve the issue) declare the difference a "validation item," meaning that it will test for itself whether the other party has made an adjustment that meets its standard. ${ }^{19}$ Regulatory cooperation in the sense of enlarging the scope of reciprocal acceptance also extends to consideration of deep changes in the nature of design standards-for example, from specifications of permissible equipment to specifications of the level of performance the proposed equipment must attain - that reflect the broad changes in the organization of production and the overall context of regulation set out above.

The governance structure created by the Agreement is accordingly designed to encourage resolution of disputes arising under current arrangements but also to extend regulatory cooperation. As its name indicates, the Bilateral Oversight Board, including representatives of the TA's (and, for the EU, representatives of the member state regulatory authorities with continuing air safety jurisdiction), reviews progress under the BASA and sets the agenda for further reform. It is the final arbiter of disputes and has explicit authority to approve new, domain-specific annexes. A Certification Oversight Board, composed of representatives of the TA's with expertise in airworthiness certification and environmental testing, and a Joint Maintenance Coordination Board, with TA representatives whose expertise is in repair, coordinate the technical discussions between the authorities in their respective domains and whenever possible resolve disputes arising from those discussions, referring only intractable ones to the Bilateral Oversight Body. This ensures that disputes are normally resolved at relatively low levels of the administrative structure, by persons likely to have deep knowledge of the issues, rather than by higher authorities with limited understanding of current practices. If a party, after the fruitless pursuit of a remedy, loses confidence in a class of approvals issued by the other, it suspends acceptance of only that kind of approval, without disturbing the remainder of the agreement. Because of this severability, each authority understands that the other could indeed act on a particularly vehement objection to a test or standard without fear of precipitating a political crisis; the credibility of this threat has a deterrent effect that reduces the chances that the power of partial suspension being exercised.

\footnotetext{
16 See EU-US BASA (2011, Annex 2X.5).

17 See EASA/FAA (2011).

18 See EASA/FAA, Technical Implementation Procedures for Airworthiness and Environmental Certification between the Federal Aviation Administration of the United States of America and the European Aviation Safety Agency of the European Union, at: https://www.faa.gov/aircraft/air_cert/international/bilateral_agreements/baa_basa_listing/media/EUTIP.pdf.

19 See Eisner and Parker (2016, p. 24).
} 
Are civil aviation and food safety exceptional cases, not examples of general tendencies in the development of regulation and regulatory cooperation? A recent study cautions against generalization, arguing that the role of ICAO as an international standard setter and the high degree of ex post liability for aviation accidents - the near certainty that negligence will be uncovered and heavily sanctionedmake the case unusual, if not singular. ${ }^{20}$ But industry-specific organizations with the authority to set minimum standards for their members and to frame the agenda for further reform are today pervasive, if not ubiquitous. The Codex Alimentarius plays this role globally for food safety (helping to diffuse HACCP-based regulation), as does the International Maritime Organization in maritime safety, and the International Conference on Harmonization in the area of pharmaceutical regulation, initially among regulators in the US, EU and Japan, and now globally. Such organizations do not displace national, bilateral or (mega-)regional regulation any more than ICAO displaces the FAA, EASA or the results of their cooperation under the EU-US BASA. In all these cases the "global" standard setter, whatever its actual scope, provides an invaluable forum for crystalizing consensus, exposing new ideas and initiatives to informed criticism, generalizing successes and at times calling attention to egregious cases of noncompliance with minimal norms. But whatever their exact role, these organizations are a common feature in the current regulatory landscape, not a distinctive outcropping that can explain the outcome in civil aviation or any other particular sector.

Ex post liability too is becoming commonplace. The spread of incident reporting systems, including the obligation to trace serious defects to their source, together with the spread of just-in-time production makes it harder and harder to escape liability for negligence: faults are registered in the course of production and failure, especially repeated and systematic failure, to take corrective action makes it difficult to disclaim liability. Imminent changes, suggested again by the trajectory of civil air regulation, could well make liability all but inescapable. Through the 1970s improvements in air safety largely resulted from investigation of aircraft accidents. As the number of accidents declined, reports of incidents - out-of-control events that could lead to accidents-spurred further improvements. As the number of incidents declines ICAO now argues that emergent hazards are best detected by continuous, real-time monitoring of engines and aircraft. ${ }^{21}$ This example, too, could be multiplied.

Nonetheless, the cases presented might be exceptional on other grounds. However much they might ramify - aircraft safety involves design, manufacturing, maintenance and operations; food safety spans farms, processing, retail distribution - these domains may be discrete or bounded in the sense that they do not implicate what we might think of roughly as core sovereign prerogatives such as the monopoly control of force or the power of taxation. Regulation in other areas might, however, lead to such a "sovereigntist" ascent, the anticipation of which might stop efforts at mutual accommodation through regulatory equivalence before, or as they begin. A case in point might be banking and other financial services, where, as the recent financial crisis showed, failures of regulation in one jurisdiction can be rapidly transmitted to others, with catastrophic consequences. Within the EU, for instance, efforts to establish regulatory equivalence in banking may have touched off such an upward progression. To list only the most prominent reforms under discussion: regulatory equivalence requires equivalent systems of deposit insurance, of resolution of insolvent banks, of common, risk-adjusted capital reserve requirements (which must be compatible with Basel IV international standards now under construction) and of a "single rule book" for evaluating the underwriting practices of systematically important and ordinary banks. ${ }^{22}$ Perhaps these regulatory domains are so intertwined that they can only be managed by a single, central authority, so the search for mutual adjustment through regulatory equivalence results in the creation of a de facto banking or financial-markets sovereign, if not a new sovereign tout court? If there were many such domains regulatory equivalence would remain marginal and the choice might

\footnotetext{
20 See Eisner and Parker (2016).

21 See Ratajczyk (2011, p. 401); Jennison (2013, pp. 349-50).

22 See generally on EU banking reform: Ferran (2014, pp. 16-34); Zeitlin (2016, pp. 1077-83).
} 
be, in fact, between a global technocracy and more or less democratically accountable megaregional ones.

The main counter consideration is that under uncertainty, regulatory homogeneity is unacceptably risky. Imposing uniform rules (for example, treating sovereign debt as riskless) is a recipe for disaster when, as all but inevitably happens, some of the uniform rules are inapplicable or unintentionally induce risky behavior themselves. By the same token, uniform requirements choke off the exploration of diverse, contextualized responses to local conditions and with them the possibilities of mutual learning that, as argued repeatedly here, is indispensable to rapid adjustment under uncertainty. Such considerations are very much in evidence in the EU debate on banking reform, as counterweights to arguments for centralization and uniformity. The Chair of the Supervisory Board of the Single Supervisory Mechanism for European Banks (European Central Bank), which helps create the framework for and monitors the results of banking supervision in Member States, cautioned against "pursuing a one-size-fits-all supervision" in favor of an approach that ensures "consistency across institutions and supervision tailored to credit institutions' specificities" to "accommodate banking diversity" - considered to be "very desirable from a financial stability perspective." 23 How to institutionalize a framework maintaining consistency while allowing and learning from diversity - the stuff of regulatory equivalence-remains open question in this and other domains. But in this case, at least, the apparent exception accords with the rule. ${ }^{24}$

Under the EU's leadership international regulatory cooperation in data privacy may well develop in analogous ways, with important spillovers in competition law. These examples, together with the extensive but incomplete changes in the governance of trade in forest products discussed earlier, are too numerous, and each too important in its right, to be outliers. They are more likely to be forerunners. For now, we simply regard them as illustrative of the broad changes reshaping regulatory cooperation as regulation becomes more and more central to trade.

\section{The WTO: stuck in a rut?}

The WTO is not adapting to these changes. It struggles to perform routine, core functions such as dispute resolution and the provision of current, complete and correct information on national trade policies. Its ability to fulfill its mandate is in question. ${ }^{25}$ The WTO's prospects as a convener of trade negotiations are likewise threatened, although as noted below there are nascent green shoots associated with the launch of initiatives that could evolve into OPAs. Members failed to conclude the first round of multilateral trade negotiations launched under WTO auspices in 2001, the Doha Development Agenda. The failure of the Doha round in turn has precluded discussion of a new work program that includes the regulatory subjects increasingly central to polities and international business. Instead, this was taken up by many countries in the context of PTAs. ${ }^{26}$

The WTO has been deadlocked by shifts in the power balance among its members, by working practices that magnify the paralyzing effects of those shifts, and by constitutional limits on the acceptable forms of international cooperation within the global trade regime. The new, unstable balance or imbalance of power will persist, but recent developments suggest the constitutional understanding of the WTO may be interpreted more permissively, to allow precisely the kinds of deep international regulatory cooperation among groups of countries, without the prior consent of all members, that could lead by means of OPAs and other instruments to the elaboration of norms and procedures which could in time become broadly consensual.

\footnotetext{
23 See Nouy (2015).

24 For in-depth discussion of this area, see Ferran (2014; 2018) and Moloney (2018).

25 See Bertelsmann Stiftung (2018) for an in-depth discussion.

26 See, for example, Bollyky (2017), Chase and Pelkmans (2015), and Mumford (2014, 2018).
} 
The redistribution within the WTO of power, from the advanced countries that presided over the creation of the organization to the countries with rapidly growing economies that now contend for influence within it, is common knowledge. Developing and emerging economies have come to account for almost half of the value of global merchandise trade and global GDP. Many rapidly advancing countries no longer suffer the hegemony of the founding powers, such as the US; China openly challenges it. Nor are the former hegemons eager to reassert their authority within the multilateral system of their own creation. While growth in international trade, cross-border investment and knowledge flows have supported major reductions in global poverty and increased real incomes of hundreds of millions of people in low-income countries, these developments have coincided with a decline in relatively unskilled employment in manufacturing in OECD member countries. For many trade has become a potent symbol of a congeries of alarming and apparently uncontrollable technological, economic and political changes. In virtually all advanced countries, broad coalitions of parties and civil society groups on the left and the right oppose trade agreements and the WTO as visible embodiments of globalization.

To the burdens on decision making created by the assertiveness of rising powers and the hesitations of the former hegemon must be added the burdens that result from WTO decision-making conventions, especially the working practice that decisions are to be taken by (unanimous) consensus, and the convention that developing countries are to be accorded special and differential treatment (Bertelsmann Stiftung, 2018). The first permits any WTO member to veto initiatives and block efforts that seek to go beyond the issues agreed to comprise the (stalled) Doha Development Agenda. The second has allowed advanced developing countries to offer less than full reciprocity in trade negotiations and the application of certain WTO rules. Such systematically lop-sided arrangements are no longer acceptable to many high-income countries, first and foremost the US. But many developing countries view special and differential treatment as a basic feature of the bargain underpinning the WTO.

Decision by consensus is especially revealing of the self-understanding of the WTO because it holds sway in disregard of the formal admissibility of other procedures. Majority voting is allowed under the WTO's governing statues, but voting does not occur. To vote, it is widely held, would undermine the legitimacy of WTO decisions. ${ }^{27}$ Countries large and small rely on the consensus practice as a guarantee that the results of negotiations are acceptable to them, ensuring the 'ownership' of the WTO by members and their polities. Thus legitimated, consensus decision-making is also used to block activities that have nothing to do with negotiations, such as setting the agenda of committee meetings or proposals to discuss a trade policy-related matter that is not covered by a WTO agreement or not part of the Doha Development Agenda. The result has been that new rule making has largely migrated to PTAs, rather than being conducted under the auspices of the WTO.

The same insistence that substantial additions or departures from existing rules-lawmakingrequires (unanimous) consensus among the members sharply limits the forms of international cooperation in trade that the WTO recognizes as compatible with membership in the general body of the organization. Three options currently exist for groups of WTO members to collaborate on a policy area. ${ }^{28}$ First, PTAs, the most familiar, are economic integration agreements in which signatories liberalize substantially all trade in goods (General Agreement on Tariffs and Trade (GATT) Art. XXIV)

27 Some WTO provisions specify consensus as the decision-making rule, e.g., Art. X:9 on amendments to include new Annex 4 Plurilateral Agreements. Art. IX WTO specifies that if voting occurs, unanimity is required for amendments relating to general principles such as non-discrimination; a three-quarters majority for Interpretations of provisions of the WTO agreements and decisions on waivers; and a two-thirds majority for amendments relating to issues other than general principles. Where not otherwise specified and consensus cannot be reached a simple majority vote is sufficient. Art. X provides that a member cannot be bound by a vote on an amendment that alters its rights or obligations and that it opposes. In such instances, the Ministerial Conference may decide to request that the member concerned withdraw from the WTO or to grant it a waiver.

28 The term plurilateral is sometimes used to describe all three of these possibilities, giving rise to potential confusion. For in-depth discussion of WTO-consistent cooperation among subsets of WTO members see Lawrence (2006) and Hoekman and Mavroidis $(2015 ; 2017)$. 
and/or remove substantially all discrimination against each other's providers of services across a broad range of sectors (General Agreement on Trade in Services (GATS) Art. V). Second, critical mass agreements (CMAs), in which a group of countries agrees to specific policy commitments that are inscribed into their WTO schedules and apply on a non-discriminatory basis to all WTO members. Third, Plurilateral Agreements (PAs) (under Art II:3 WTO), in which a club agrees to undertake specific commitments in a policy area and restricts the benefits of cooperation to club members.

The major example of a WTO CMA is the Information Technology Agreement (ITA). This abolishes tariffs on information technology products. The ITA has 82 participants, including the $28 \mathrm{EU}$ member states, and has increased global trade substantially in electronic products. ${ }^{29}$ CMAs have also been concluded for services sectors - an example is a Reference Paper on regulation of basic telecommunications whose signatories commit to apply specific regulatory disciplines on a nondiscriminatory basis to all WTO members. ${ }^{30}$ Negotiations on a possible Environmental Goods Agreement spanning the EU and 17 other WTO members are an example of an ongoing critical mass negotiation. ${ }^{31}$

The disciplines established by CMAs apply only to the subset of WTO member countries that sign on to them; but the benefits extend on a most-favored-nation basis to all members, including those that do not participate. Because commitments are implemented on a nondiscriminatory basis such agreements do not require consensus for incorporation into the WTO - those WTO members that decide to join a CMA can simply inscribe the provisions of the agreement into their schedules of commitments under the GATT and/or the GATS, as appropriate (Hoekman and Mavroidis, 2017). The two key features of CMAs are that they are open - the presumption is that any WTO member can participate if it desires to, whether as part of the group that initially agrees to pursue cooperation on a matter, or after the establishment of an agreement - and that they are applied on a MFN basis. OPAs are a form of CMA.

CMAs differ from the third type of agreement-WTO Art. II.3 PAs - in that the benefits of PAs can be limited to signatories. The main example of a PA is the Government Procurement Agreement (GPA). Because WTO PAs can apply in a discriminatory manner, their incorporation into the WTO is subject to the approval of all WTO members, including those that do not join. Art. X.9 WTO stipulates that the Ministerial Conference of the WTO may decide to add a new Plurilateral Agreement to the existing ones 'exclusively by consensus'. Thus, the bar for adoption of new PAs is very high, as consensus allows any one member to block the incorporation of a new agreement.

Each of these three forms of cooperation among groups of WTO members respects the consensus principle - the juri-generative capacities of the members of the WTO in their unanimity - but does so in different ways. PTAs honor the principle by emulation, adopting it as their own: They are formed by a comprehensive consensus of the parties that mirrors in the scope of the topics it covers, but not the extent of its membership, the ideal of the WTO itself - a consensus within a consensus. CMAs are exempted from application of the consensus principle but only because they only create new facilities for nonparties, and never limit existing ones. As a result, they are not deemed to require assent of the sovereign body of members. The situation of PAs is the reverse. They do limit the rights of nonparties, and therefore are subject to consensus requirements so onerous they are seldom met.

To some extent the WTO already incorporates elements of regulatory cooperation on the lines of OPAs, and recent developments suggest substantial, further opening. For example, the WTO agreements on Technical Barriers to Trade (TBT) and Sanitary and Phytosanitary (SPS) measures call on members to base their product regulation on international standards where these exist. Since international standard

\footnotetext{
29 See Gnutzmann-Mkrtchyan and Henn (2018) for estimates of the global trade impact of the ITA.

30 Eighty-two WTO members have signed the Reference Paper. See https://www.wto.org/english/tratop_e/serv_e/telecom_e/telecom_e.htm.

31 Negotiations commenced in July 2014. See https://www.wto.org/english/tratop_e/envir_e/ega_e.htm.
} 
setting has some of the aspects of mutual interrogation and continuous adjustment characteristic of OPAs, the TBT and SPS provisions can be thought of as an obligation to incorporate the output of OPAs into member regulation when possible. ${ }^{32}$ The obligation is not binding. WTO members are free to use national product standards as long as these do not restrict trade unnecessarily and are applied on a nondiscriminatory basis. But the presumption is that if international standards are used these cannot be contested. In the same vein provisions in the TBT agreement and the GATS encourage WTO members to establish mutual recognition agreements (MRAs). MRAs concluded between two or more WTO members must be open to participation by additional members who meet requirements: closed MRAs are explicitly prohibited- again a key feature of any OPA.

The December 2017 Ministerial Conference in Buenos Aires announced a more direct challenge to the convention of consensus. Different groups of WTO members launched discussions on four new areas: on policies to assist micro, small and medium-sized enterprises (MSMEs); e-commerce; investment facilitation; and domestic regulation of services. WTO members that joined these groups demonstrated that the consensus working practice cannot be used to prevent groups of countries discussing issues of common interest. ${ }^{33}$ These initiatives offer hope for multilateral cooperation on the model of the OPA, and with it the possibility of the regeneration of the WTO as an institution. The agreement among 76 WTO members at the 2019 annual meetings of the World Economic Forum in Davos to launch negotiations on rules to govern e-commerce and associated cross-border data flows illustrates this may be the shape of things to come. ${ }^{34}$

\section{OPAs: sovereignty-preserving international regulatory cooperation}

The account above of the process of establishing elements of mutual recognition between Food Safety Canada and the USDA and of the operation of the US-EU BASA counts as a kind of existence proof of OPAs. They can work in practice. But, reprising an old philosophers' joke, we might wonder whether they can exist in theory? The question is not idle for there is an important puzzle: The type of agreements described in Part 2 above are subject to continuing political oversight and revision. They are unilaterally severable. In these ways they are non-binding. How can they at the same time generate rules and norms that guide regulators and commercial actors (affording, for instance the assurance of stability of the regulatory environment necessary to invest), and do this without in the end delegating authority to unaccountable bodies? To find a solution it is helpful to briefly develop a further implication of uncertainty in reshaping the circumstances of commercial exchange under globalization.

Uncertainty figured in the earlier discussion of the increasing centrality and changing role of regulation and trade in two ways: as a cause of the reorganization of production-from vertically integrated to disintegrated, and from traditional to just-in-time production - and as a cause of increasing regulatory emphasis on ex post incident reporting of latent hazards that escaped ex ante review. A third, general effect of uncertainty is to transform contracting relations between innovative firms. Under relatively stable conditions, contracts between sophisticated parties are exchanges of highly detailed promises (and the penalties in case of breach). As the economy becomes more innovative and firms increasingly operate at the edge of established solutions, neither party can say exactly what is feasible. The nature of collaboration changes from a precise division of labor to a joint exploration of possibilities. In these cases, no particular outcome of the collaboration can be specified in advance; indeed, at the

32 See, e.g., Wijkström and McDaniels (2013) and Mavroidis (2016) for discussion of the SPS and TBT agreements.

33 Participation in these groups spans a broad cross-section of the membership. The EU participates in all four groups. The US is part of one (e-commerce). China was a sponsor of three of the four groups - it decided not to join the group on ecommerce. India as well as many African countries decided not to be part of any of the groups. Independent of whether a WTO member is a sponsor/supporter of a group, deliberations of the groups are open to all. China, for example, reportedly is an active participant in the discussions on e-commerce (interview with WTO official, October 4, 2018). 
farthest frontier of practical knowledge collaboration can end in failure to produce any useful outcome at all. Only if such collaborations produce marketable results do purchase orders (in the case of components entering supply chains) obligate the supplier to produce and the buyer to pay for specified quantities of the good at a certain date and price.

Under these circumstances the nature of contract itself changes. Instead of defining precisely each party's obligations, the contract establishes broad goals and a regime for evaluating achievement of them: regular, joint reviews of progress towards interim targets or milestones, as well as procedures for evaluating results and resolving disagreements in interpretation. The information exchanged under such contracts allows each party to evaluate the capacities and good faith of the other, and in so doing the prospects of both the particular project and joint efforts generally. As collaboration progresses, each party comes to rely increasingly on the capacities of the other, deterring opportunistic defection even in the absence of an explicit commitment to purchase anything in advance. Put another way, the formal requirements of the contract - the obligations of regular review and deliberate consideration of the interim results - create the conditions in which informal norms and self-interested calculations bind the parties to continue promising collaboration in good faith (Gilson, Sabel and Scott, 2009).

Regulatory cooperation of the kind between the US and Canada in food safety and the US and the EU in civil aviation are instances of regulator-to-regulator contracts of the same novel type. In these cases, the exploration of the possibility of regulatory equivalence entails no obligation to find it; and once equivalence has been established, it must be re-established by periodic review. This disciplined reciprocal scrutiny leads to protocols for reciprocal review of procedures and-in the more mature case of civil aviation-governance institutions whose jurisdiction ranges from local dispute resolution to joint formulation of new rules. These protocols and governance institutions give each party warranted confidence in the robustness and adaptability of the other, increasing the breadth and depth of their shared understandings and making it less and less likely that either will exercise the continuing right to unilaterally end cooperation. Long-term mutual reliance is thus the outcome of continuing mutual review, not of an initial commitment to long-term collaboration or hard rules on processes or policies. As far as we can tell these agreements are subject to at least the same scrutiny as normal administrative rule making. Indeed, because they are examined in the mirror of the partner's ongoing reviews, they are if anything scrutinized more carefully. In short, OPAs will always be under review. Because the rules are never fixed and final, or delegated for interpretive purposes to an autonomous, international entity, they are subject to ongoing sovereign and democratic control. But this same process of joint articulation of norms binds the parties by making them reliant on each other, and on rules that fit their changing circumstances, in accord with their values, because they make them together.

\subsection{How the WTO can make OPAs truly open and OPAs can open the WTO}

If OPAs flourish, we have argued, they can play a vital role in helping the WTO members articulate the norms and procedures to address the increasingly important question of regulatory diversity in ways that respect their sovereignty without relying on the paralyzing constitutional convention of the consensus of the members. But for OPAs to flourish they must be truly open - accessible to countries who may lack the resources and expertise to meet regulatory requirements established by OPA members or to defend their interests in disagreements over what regulatory arrangements count as equivalent. The WTO can provide valuable assistance in the form of technical support and facilitation of dispute resolution. In doing so it can in both cases build on the substantial foundations recently created by the Trade Facilitation Agreement (TFA).

The TFA, concluded in 2013, is the first multilateral agreement negotiated under WTO auspices. It comprises a set of agreed good practices in the area of trade facilitation. A central feature of the TFA is to help individual members adopt the good practices. It incorporates innovative measures for providing 
technical support that could be adapted to the related task of helping members join OPAs. ${ }^{35}$ Under the TFA developing and least-developed countries experiencing difficulties meeting implementation deadlines notify the Committee on Trade Facilitation - the secretariat established to administer the agreement - and prepare a self-evaluation of the causes and remedies of the problems. The Committee then appoints an Expert Group with 5 highly qualified members; the Group reviews the self-assessment of incapacity and accepts or amends its findings; and the Committee upon final review approves a plan of technical support. Just such a procedure could be used to determine whether and in what form the WTO should provide technical support to members struggling to join particular OPAs. Analytically the TFA has an important affinity with the OPA: Membership in both is open to all WTO members, but on condition that candidates demonstrate the equivalence of their regulatory measures and procedures in a particular domain with those of the current regime. ${ }^{36}$

Because if this affinity the expert groups of created under the TFA could serve as a template or building block for creating a dispute resolution mechanism to address differences between an OPAs as a body and a candidate member as to whether the latter's standards and institutions in the relevant domain meet the equivalence test or on the path to meeting it. Such judgements necessarily fuse normative and technical criteria. Review of decisions by an expert group would help distinguish the most nearly technical aspects of the difficulties and suggest concrete measures to address them. At a minimum such review, and the responses it prompts, would help clarify the reasons for persistent objections and implicitly — in time, perhaps explicitly — set standards for the depth and extent of reason giving expected as justification of such decisions. This type of review, together with the joint, "internal" review of requests for membership that would presumably be undertaken as a matter of course by the existing parties to an OPA would ensure that the agreements are as open as they claim to be. Cumulatively the decisions of such expert bodies would create a kind of meta-standard establishing tests to determine whether the breadth and depth of the review of a candidate's formal procedures and institutional practices is sufficiently searching and attentive to the possibility that divergent means can achieve shared ends to count as legitimate. ${ }^{37}$

Expert groups on the model of the TFA could, in addition to dispute resolution, play an important, active role in ensuring that OPAs fulfill their promise of opening the WTO to emergent, potentially consensual regulatory norms and novel procedures. Expert groups reviewing disputes in different OPAs covering the same general domain - clubs with different standards and members-would be in an excellent position to identity possible commonalities in their approaches or suggest measures to bridge differences. At the least, the circulation of these expert groups would encourage the more general circulation of ideas among overlapping OPAs and at best it would help crystallize consensus when views and practices do begin to converge. The regular operation of the WTO would thus enable groups of parties to trade on terms that reflect their distinctive values while achieving consensus when possible through this exploration of difference.

\section{Conclusion}

Differences in regulation across jurisdictions for tangible and intangible products may impede trade by generating redundant transactions costs or segmenting markets (OECD, 2017). Regulation is now a prominent feature of trade policy and increasingly is being considered in the design of PTAs (Mumford,

35 See Hoekman (2016) for an in-depth discussion and assessment of the TFA.

36 The TFA differs from the OPA in that membership in the former is ultimately obligatory, even if on a schedule that respects the candidates' capacities and idiosyncrasies; and sub groups of members may not form an alternative trade facilitation regime.

37 ISEAL is a meta-standard setter for organizations that define sustainability standards and establish procedures for certifying compliance with them; the Global Food Safety Initiative (GFSI) plays a similar role for private organizations developing certification programs for food safety management systems. See ISEAL (2014) and GFSI (nd, version 7.2). 
2018). Prominent examples are the CPTPP, recent EU agreements with Canada and Japan and the failed negotiations on a transatlantic trade and investment partnership between the EU and the US. Until recently WTO members have been unable to engage in deliberations to extend WTO disciplines to cover regulatory policy areas that are not or incompletely covered by existing agreements. One reason for this are WTO working practices - notably consensus and special and differential treatment for developing countries (Bertelsmann Stiftung, 2018) - that have impeded the pursuit of cooperation among groups of WTO members to address issues of common concern.

This constraint was relaxed at the 2017 Ministerial Conference in Buenos Aires, which saw the launch of plurilateral discussions on both old and new subjects, potentially opening the door to OPAs. Four "joint initiatives" were launched in Buenos Aires, one of which (on e-commerce and cross-border data flows) was transformed into a plurilateral negotiation group in early 2019. Insofar as these initiatives result in OPAs among groups of WTO members they offer the prospect of reducing regulatory compliance costs for firms operating internationally while enhancing the ability of regulatory agencies to attain societal objectives more efficiently. Providing a forum where countries can consider cooperation in a specific area of regulation is valuable. Having a (WTO) standard form for new, domainspecific regulatory cooperation agreements (OPAs) can substantially cut transaction costs of cooperation for countries while offering a credible prospect of gradual multilateralization. This is not a strong feature of the forms of regulatory cooperation observed in PTAs (which are generally closed) or those pursued, often bilaterally, on a sectoral basis, some of which we have discussed in this paper.

Clearly not all types of regulatory cooperation are appropriate for consideration in OPAs under WTO auspices. For example, OPAs are less suitable to address the negative spillover effects of explicitly discriminatory policies that give rise to terms of trade effects, as free rider concerns will arise that may preclude small group cooperation. Many regulatory policy areas that give rise to trade costs do lend themselves to OPAs, however, as free riding concerns either do not arise or can be addressed. The scope for OPAs may be larger than is perceived by economic policymakers. ${ }^{38}$

It is an open question whether a regulatory OPA — or an undertaking to explore the possibilities of agreement - concluded outside the WTO counts more credibly (to a skeptical civil society) as a new, stand-alone form of cooperation than the same agreement concluded inside the WTO. In our view formal recognition of OPAs as a new kind of arrangement, entailing no obligation to agree in the end to cooperate and the severability of eventual agreements offers an avenue for regenerating the WTO by assisting countries to reduce the trade costs of regulatory differences while improving regulatory outcomes. Not pursuing this route would be to miss an opportunity to revitalize the WTO. Perhaps more important is the scope that OPAs offer to participants and stakeholders to multilateralize sectoral regulatory cooperation initiatives of the type discussed above that are proliferating outside the ambit of trade agreements, and to some extent are reflected in recent PTAs. Such arrangements tend to be closed or lack explicit mechanisms to consider, let alone encourage, participation by additional countries. OPAs can help support the gradual multilateralization of international regulatory cooperation initiatives that address matters that are of potential interest to many countries, by helping to enhance transparency, encourage mutual review, support learning, and provide a platform to strengthen regulatory capacity in countries where needed to be able to participate in a given OPA.

38 Indeed, even a conflictual policy area such as subsidies arguably lends itself at least to some extent to an OPA. For example, the type of review and reasoning that is part of any OPA is needed in the subsidies context given that their potential salience in addressing market failures and achieving social objectives makes it much harder to write down hard rules. The design of any rules and their implementation must be informed by an understanding of the underlying goals (as elucidated by the government using them), and neutral assessments of their effects. 


\section{References}

Asser Institute. 2017. EU Timber Regulation: From an operator's perspective. Retrieved from https://www.asser.nl/DoingBusinessRight/Blog/post/towards-a-due-diligence-jurisprudence-the-eutimber-regulation-s-requirements-in-courts-by-wybe-th-douma.

Baldwin, R. 2016. The Great Convergence: Information Technology and the New Globalization. Cambridge, MA: Harvard University Press.

Bertelsmann Stiftung. 2018. Revitalizing Multilateral Governance at the World Trade Organization. At https://www.bertelsmann-stiftung.de/en/publications/publication/did/revitalizing-multilateralgovernance-at-the-world-trade-organization/.

Bollyky, T. 2017. "The Role of Regulatory Cooperation in the Future of the WTO," RTA Exchange. Geneva: International Centre for Trade and Sustainable Development and Inter-American Development Bank.

Chase, P. and J. Pelkmans. 2015. This time it's different: Turbo-charging regulatory cooperation in TTIP. CEPS Special Report No. 110.

Chayes, A. and A. Chayes, 1993. "On compliance," International Organization, 47(2): 175-205.

Chayes, A. and A. Chayes. 1998. The New Sovereignty: Compliance with International Regulatory Agreements. Harvard University Press.

Conconi, P. and C. Perroni, 2002. "Issue linkage and issue tie-in in multilateral negotiations," Journal of International Economics, 57(2): 423-47.

Dür, A., L. Baccini and M. Elsig. 2014. "The Design of International Trade Agreements: Introducing a New Dataset." Review of International Organizations 9 (3): 353-375.

Eisner, N. and R.W. Parker. 2016. "Learning from Experience: Three Case Studies in International Regulatory Cooperation," Report Prepared for the European Commission. At: doi:10.2139/ssrn.2780605.

EU-US BASA. 2011. International Agreements Council Decision of 7 March 2011 concerning the conclusion of the Agreement between the United States of America and the European Community on cooperation in the regulation of civil aviation safety (Official Journal of the European Union 291, 9.11.2011). Retrieved from http://eur-lex.europa.eu/resource.html?uri=cellar:64d9e1a2-633c4e91-bbf5-053e5ab1b432.0010.02/DOC_1\&format=PDF.

European Aviation Safety Agency and the Federal Aviation Administration. (2011). Agreement/Annex 2/ Maintenance (The Aviation Safety Agreement Between The United States and The European Community, EASA/FAA Workshops in the US presentation, August/September 2011, Slide 23). Retrieved from https://www.faa.gov/aircraft/repair/media/EASA_EU_roadshows.pdf.

Ferran, E. 2014. Financial Supervision. In Mügge, D. (ed.), Europe and the Governance of Global Finance. Oxford: Oxford University Press, 16-34.

Ferran, E. 2018. Regulatory Parity in Post-Brexit UK-EU Financial Regulation: EU Norms, International Financial Standards or a Hybrid Model? In K. Alexander, C. Barnard, E. Ferran, A. Lang and N. Moloney, Brexit and Financial Services: Law and Policy. Hart Publishing.

Food and Drug Administration. 2010. International Comparability Assessment Tool (ICAT) (International Interagency Coordination). Retrieved from: https://www.fda.gov/downloads/Food/InternationalInteragencyCoordination/UCM331177.pdf.

Food and Drug Administration. 2013. Report of the Systems Recognition Assessment of Canada (International Agency Coordination). Retrieved from https://www.fda.gov/downloads/Food/InternationalInteragencyCoordination/UCM503960.pdf. 
Global Food Safety Initiative. nd. Requirements for the management of certification programs, version 7.2. Retrieved from https://www.mygfsi.com/files/Technical_Documents/BR_V7.2/Benchmarking_Requirements_v72_Part2.pdf.

Gilson, R., C. Sabel and R. Scott. 2009. "Contracting for Innovation: Vertical Disintegration and Interfirm Collaboration." Columbia Law Review 109(3): 431-502.

Gnutzmann-Mkrtchyan, A. and C. Henn, 2018, "Peeling away the layers: Impacts of durable tariff elimination," Journal of International Economics, 115: 259-76.

Hoekman, B. 2016. "The Bali Trade Facilitation Agreement and rulemaking in the WTO: milestone, mistake or mirage?" in J. Bhagwati, P. Krishna and A. Panagariya (eds.), The World Trade System: Trends and Challenges. Cambridge: MIT Press, 149-92.

Hoekman, B. and P. Mavroidis, 2015. Embracing Diversity: Plurilateral Agreements and the Trading System. World Trade Review, 14(1), 101-16.

Hoekman, B. and P. Mavroidis, 2017. "MFN Clubs and Scheduling Additional Commitments in the GATT: Learning from the GATS," European Journal of International Law, 28(2): 387-407.

Hofmann, C., A. Osnago and M. Ruta, 2018, The Content of Preferential Trade Agreements, World Trade Review, At: doi:10.1017/S1474745618000071.

Humphrey, J. 2012, "Convergence of US and EU Production Practices Under the New FDA Food Safety Modernization Act." The World Economy 35(8): 994-1005.

IKEA. 2018. EU Timber Regulation: From an operator's perspective. Presentation to the Commission Expert Group on EU Timber Regulation and the Forest Law Enforcement, Governance and Trade (FLEGT) Regulation (main group). Retrieved from http://ec.europa.eu/transparency/regexpert/index.cfm?do=groupDetail.groupMeetingDoc\&docid=2 5128.

International Civil Aviation Organization. 2007. Outlook for Air Transport to the Year 2025 (ICAO Circular Cir. 313 AT/134).

ISEAL. 2014. Setting Social and Environmental Standards ISEAL Code of Good Practice Version 6.0. Retrieved from https://www.isealalliance.org/sites/default/files/resource/201711/ISEAL_Standard_Setting_Code_v6_Dec_2014.pdf.

Jennison, M. 2013. 'The Future of Aviation Safety Regulation: New US-EU Agreement Harmonizes and Consolidates the Transatlantic Regime, but What is the Potential for Genuine Regulatory Reform?' Air \& Space Law 38, no. 4\&5: 333-350.

Lawrence, R. 2006. "Rulemaking Amidst Growing Diversity: A 'Club of Clubs' Approach to WTO Reform and New Issue Selection.” Journal of International Economic Law, 9(4): 823-835.

Limão, N. 2005. "Trade policy, cross-border externalities and lobbies: do linked agreements enforce more cooperative outcomes?" Journal of International Economics 67: 175-99.

Limão, N. 2016. "Preferential Trade Agreements," in K. Bagwell and R. W. Staiger (eds.), The Handbook of Commercial Policy, vol. 1B. Amsterdam: North-Holland, 279-367.

Maggi, G. 2016, "Issue Linkage," in K. Bagwell and R. Staiger (eds.) The Handbook of Commercial Policy, vol. 1B, Amsterdam: North Holland, 513-64.

Mavroidis, P.C. 2016. The regulation of international trade: the WTO agreements on trade in goods, vol. 2. Cambridge: MIT Press.

Moloney, N. 2018. The Age of ESMA. Governing EU Financial Markets. Hart Publishing. 
Mumford, P. 2014. "Regulatory Coherence: Blending Trade and Regulatory Policy," Policy Quarterly, 10(4): 3-9.

Mumford, P. 2018. "Regulatory Cooperation," in J. Drake Brockman and P. Messerlin (eds.), Potential Benefits of an Australia-EU Free Trade Agreement: Key Issues and Options. Adelaide: University of Adelaide Press, 149-67.

Nathan, I., Chen, J., Hansen, C. P., Xu, B., \& Li, Y. 2018. Facing the complexities of the global timber trade regime: How do Chinese wood enterprises respond to international legality verification requirements, and what are the implications for regime effectiveness? Forest Policy and Economics, 92, 169-180.

Nouy, D. 2015. Presentation of the First ECB Annual Report on Supervisory Activities at the European Parliament's Economic and Monetary Affairs Committee, European Central Bank, Brussels. Retrieved from https://www.bankingsupervision.europa.eu/press/speeches/date/2018/html/ssm.sp180326.en.html.

OECD. 2017. International Regulatory Cooperation and Trade: Understanding the Trade Costs of Regulatory Divergence and the Remedies. Paris: OECD.

Overdevest, C. and J. Zeitlin. 2015. Forest Law Enforcement Governance and Trade (FLEGT): transnational dynamics of an EU experimentalist regime. In Zeitlin, J. ed. Extending Experimentalist Governance? The European Union and Transnational Regulation: 137.

Overdevest, C. and J. Zeitlin. 2018. Experimentalism in Transnational Forest Governance: Implementing EU Forest Law Enforcement Governance and Trade (FLEGT) Voluntary Partnership Agreements in Indonesia and Ghana. Regulation \& Governance, 12(1): 64-87.

Overdevest, C. and J. Zeitlin. 2018. Experimentalist Interactions: The Emerging Timber Legality Regime and Transnational Forest Governance (draft for presentation at the ECPR General Conference, Hamburg 23-25). Retrieved from https://press.ecpr.eu/Events/PaperDetails.aspx ?PaperID=40656\&EventID=115.

Pacheco, P. G. Schoneveld, A. Dermawan, H. Komarudin and M. Djama. 2018. Governing sustainable palm oil supply: Disconnects, complementarities, and antagonisms between state regulations and private standards," Regulation \& Governance, At: doi:10.1111/rego.12220.

Palanco, L. and P. Sauvé, 2018, "The Treatment of Regulatory Convergence in Preferential Trade Agreements," World Trade Review, 17(4): 575-607.

Ratajczyk, M. 2011. 'Regulatory Framework for a 'Performance-Based' Approach to Air Safety Management in the European Union'. Air and Space Law 36(6): 401-426.

Sabel, C., G. Herrigel and P. Kristensen, 2017, "Regulation under uncertainty: The coevolution of industry and regulation," Regulation \& Governance, At doi:10.1111/rego.12146.

Turner, A. 2013. "FAA touts safety boost at half the cost," March 7. At http://www.airtrafficmanagement.net/2013/03/faa-touts-ga-safety-boost-at-half-cost/.

Vitalis, V. 2018. "National Interest Analysis for the Comprehensive and Progressive Agreement for Trans-Pacific Partnership," Statement to the Foreign Affairs, Defence and Trade Committee, May 3. At: https://www.parliament.nz/resource/enNZ/52SCFD_EVI_76583_999/0886a670ec6aa58cfc5e47172141ad4ab3e66cbc

Wijkström, E. and D. McDaniels. 2013. "Improving Regulatory Governance: International Standards and the WTO TBT Agreement." Journal of World Trade, 47(5): 1013-46.

Zeitlin, J. 2016. EU Experimentalist Governance in Times of Crisis. West European Politics 39(5): 1073-94. 


\section{Author contacts:}

\section{Bernard Hoekman}

Robert Schuman Centre for Advanced Studies, European University Institute Villa Schifanoia, Via Boccaccio 121

I-50133 Florence

and CEPR

Email: Bernard.Hoekman@eui.eu

\section{Charles Sabel}

Columbia University

Jerome Greene Hall

Room 929

435 West 116th Street

New York NY 10027

USA

Email: csabel@law.columbia.edu 